\title{
Calvin and Swaab: A comparison with respect to free will
}

\begin{abstract}
Authors:
Ammiël Meuleman ${ }^{1}$

Willem van Vlastuin ${ }^{1,2}$

\section{Affiliations:}

${ }^{1}$ Faculty of Theology, VU

University, the Netherlands

${ }^{2} J o n a t h a n$ Edwards Centre, University of the Free State, South-Africa

\section{Correspondence to:} Willem van Vlastuin

Email:

w.van.vlastuin@vu.nl

\section{Postal address:}

Jachtlaan 18, 8091 BM

Wezep, the Netherlands

Dates:

Received: 02 Oct. 2013

Accepted: 29 Apr. 2014

Published: 19 Dec. 2014

How to cite this article:

Meuleman, A. \& Van

Vlastuin, W., 2014, 'Calvin

and Swaab: A comparison

with respect to free will', In

die Skriflig 48(1), Art. \#1763,

6 pages. http://dx.doi.

org/10.4102/ids.v48i1.1763

\section{Copyright:}

(C) 2014. The Authors.

Licensee: AOSIS

OpenJournals. This work is

licensed under the Creative

Commons Attribution

License.
\end{abstract}

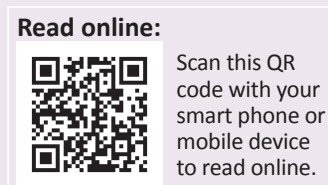

In theology and philosophy, the issue of free will is being revived. This revival seems to be initiated by the neurosciences, which, at the level of the brain, wants to give a decisive answer about the matter of free will. There are neuroscientists who think that humans are completely determined by their brain functions. The Dutch neurobiologist Dick Swaab therefore calls this 'neurocalvinism'. This article examines whether the two kinds of determinism are compatible. It will be proved that this is not the case and that the neurosciences propagate a stronger kind of determinism than Calvin and that the two therefore are different in principle.

Calvijn en Swaab: Een vergelijking met betrekking tot de vrije wil. In de theologie en filosofie is een opleving gaande als het gaat om het denken over de vrije wil. Deze opleving lijkt echter geïnitieerd door de neurobiologie, die op het niveau van de hersencellen hierover uitsluitsel wil geven. Er zijn neurobiologen die aan de hand van dit onderzoek menen dat de mens volledig gedetermineerd is. Deze visie wordt daarom, door de Nederlandse neurobioloog Dick Swaab, ook wel 'neurocalvinisme' genoemd. In dit artikel wordt onderzocht of het determinisme van Calvijn en de neurowetenschappen inderdaad kunnen worden uitgewisseld. Aangetoond wordt dat dit niet het geval is en dat de neurowetenschappen een hardere vorm van determinisme voorstaand dan Calvijn en in die zin principieel van elkaar verschillen.

\section{Introduction}

Free will has set a lot of pens in motion throughout history. Not only philosophers but also theologians have been concerned about the question as to whether humans have free will or not. ${ }^{1}$ Any answer to this question inevitably gives rise to more questions. It has been shown throughout the centuries that it is not easy to formulate a concrete, all-encompassing vision on free will. ${ }^{2}$ The current attention to free will, therefore, is not new.

What is new in the current focus on the subject of free will, however, is that it is no longer limited to philosophers and theologians but also draws interest from the media. In particular, reflections from neuroscientists have drawn much attention (Haggard \& Martin 1999; Libet et al. 1983; Wegner 2003), prompted, perhaps, by humankind's desperate search for answers about the essence and the meaning of all things, not at least existence itself. Whereas previously, in the Western World at least, theology and philosophy have sought to give answers to life's big questions, nowadays an answer given by the hard sciences is preferred. Therefore, it is not surprising that books like We are our brains (Swaab 2014) by the Dutch neuroscientist Dick Swaab and De vrije wil bestaat niet [Free will does not exist] (Lamme 2010) by the neuropsychologist Victor Lamme are in such demand.

The fact that Swaab's book has enjoyed its 14 reprints in The Netherlands and that it featured continuously in the bestsellers list for over two years is a symptom of the great interest society has

1.Names of theologians who were thinking about free will are for example Augustin (2010), Luther ([1525] 1990), Edwards ([1754] 2009), Anselmus, Lipsius and Luis de Molina. Almost all well-known philosophers have reflected more or less on free will: Descartes, Voltaire, Hume, Leibniz, Kant, Leibniz, Sartre, Daniel Dennet, Harry Frankfurt, et cetera.

2.It is striking that XX Kane in his Oxford Handbook of Free Will (Kane 2011) does not give a definition of the concept of free will. This indicates the complexity of the issue. The complexity of free will is illustrated by the interrelatedness of free will with issues such as responsibility, morality, consciousness, mind-body relationship and psychiatry (Kane 2011:40). Instead of giving a single definition of free will, Kane (1999; 2007), König (1996), Campbell (2011) and Mawson (2011) give several perspectives on free will when dealing with this issue. In general, the understanding of free will is divided into three streams. Firstly, the libertarian view does not defend that the will is free to do what it wants but that the will is free to decide what it wants. Libertarianism does not deny that man is influenced the will is free to do what it wants but that the will is free to decide what it wants. Libertarianism does not deny that man is influenced by his environment, but this influence is not so strong that human activity is merely a plaything. Representatives of this vision are for example Rene Descartes, Immanuel Kant, Roderick Chrisholm, Robert Kane amd Carl Ginet. Secondly, compatibilism seeks to make the libertarian view and determinism compatible with each other. It argues that free will is true regardless whether determinism is true or not. Compatibilists believe that fully determined actions can be seen as acts of free will. Whereas libertarians say that free will means that one is free to do determine what one wants, compatibilists say that free will is the possibility that one is free to what one want to do (or not). It is a hypothetical freedom. Important representatives of this vision are Thomas Hobbes, Jonathan Edwards, David Hume, G.E. Moore, Daniel Dennet and Harry Frankfurt. Thirdly, determinism postulates that no one has a free will because everything is already fixed. Choices have already been made by (in religious determinism) God or (in natural determinism) by the causal necessity of natural law. Important representatives of this vision are for example Martin Luther, Baruch Spinoza, Laplace, Derk Pereboom. 
for the issues which are at stake in this area of research. ${ }^{3}$ These neurobiological concerns touch upon important questions about responsibility, accountability, morality and autonomy. At its core, the issue of free will has to do with the real identity of the human being. This clarifies that the issue of free will is not only of biological interest but also theological interest. Given this context, it is understandable that the current resurgence of interest in the issue of free will has resurrected the former theological interests. At the moment, we are seeing increasing interdisciplinary cooperation and research between (neuro)science and theology ${ }^{4}$, which indicates the relevance of the theological interest in neuroscientific developments and vice versa.

Swaab himself links the outcomes of his research with theology by referring to Calvinism in order to clarify the determinism which he defends (Swaab 2014):

Our behavior is determined from birth. This view - the polar opposite of the belief in social engineering that held sway in the 1960s - has been referred to as 'neurocalvinism', alluding to the doctrine of predestination that shaped Calvinistic thinking. To this day, adherents of strict Protestants sects believe that God has predetermined the course of everyone's life from the moment of birth, including whether you will go to heaven or hell. (pp. 327-328)

These sentences clarify that Swaab has a deterministic worldview and that he assumes that the structure of Calvinistic theology and self-understanding is accordingly deterministic. He presupposes a comparable or at least an analogous understanding of reality in general and in human identity in particular.

This raises the question as to whether the understanding of free will in neuroscience is in fact as consistent with Calvin's view of will as Swaab suggests. Can Calvin's view be swapped for Swaab's so that God within Calvinism can simply be replaced by the brain or the natural course of things?

There are good reasons to relate Calvin's theological worldview with Swaab's understanding of free will. Firstly, such research belongs to the current tendency of interdisciplinary research between neuroscience and theology. ${ }^{5}$ Secondly, both neuroscience and theology are interested in the same issue of free will and human identity (Van Ruler 2011). Thirdly, Christian history has a rich tradition of cumulative wisdom in investigating the issue of free will. Fourthly, Swaab refers explicitly to the Calvinistic tradition. Fifthly, Calvin can be seen as a mirror to understand classic

\section{See Debestseller60 (n.d.)}

4.The Institute for the Biocultural Study of Religion speaks about 'neurotheology'. This institute publishes the magazine Religion, Brain and Behavior, indicating the relationship between theology and neurobiology. Some recent publications in several languages in this area are from P. Oomen (Oomen 2013), R. Swinburn several languages in this area are from (2013) and W. Achtner (2010). See also the special issue of Philosophia Christi (2013) 'Neuroscience and the soul: Philosophical issues' and the Conference of the European Society for Philosophy of Religion in 2012 which was dedicated to the theme of 'Embodied religion'. Several contributions at
result of interdisciplinary research (Jonkers \& Sarot 2013).

5.Compare Wilfried Härle (2006) and Willem van Vlastuin (2012a; 2012b). The approach in these essays differs structurally from the research in the current essay.
Christianity, on the one hand, and he belongs to modern time with special interest in the human subject, on the other hand.

The foregoing considerations lead to the conviction that it is useful to investigate the understanding of free will by a representative neuroscientist, namely Dick Swaab, within a Calvinistic framework. This leads to the following research question: Is Dick Swaab's understanding of free will compatible with Calvin's? The research question will be addressed as follows. Firstly, some of the basic structures of Calvin's understanding of free will in relationship to God's all-determinative control of human beings are investigated. Secondly, the basic structures of Swaab's understanding of free will in relationship to the brain's all-determinative control of human beings are investigated. Thirdly, in the conclusion, both concepts are related to each other so that conclusions can be drawn.

\section{Calvin and free will}

In this section, the problem of free will in Calvin's vision will be discussed from two perspectives. Twice in his Institutes, Calvin speaks about free will. The first reference is when writing on the creation of man in the image of God (Calvin [1559] 1863:169), and the second reference is when writing on the redemption of sin by Christ (ibid:222). He wants to draw this distinction because the distinction between the two conditions of man, pre-lapsum (before the fall into sin) and post-lapsum (after the fall into sin), must be made clear (ibid:159; Lane 1981)

\section{Image of God}

When Calvin argues about free will from the perspective of the creation of humankind, he sees man as made by God in his image, completely good and without sin. When Calvin ([1559] 1863:169) argues that the role of the will is '... to choose and follow what the intellect declares to be good, to reject and shun what it declares to be bad', he is speaking about human nature pre-lapsum. ${ }^{6}$ According to Calvin, at this stage, humans were able to choose between good and evil by their free will. This is evidenced by the following quote (ibid):

Man [sic] excelled in these noble endowments ${ }^{7}$ in his primitive condition, when reason, intelligence, prudence, and judgment not only sufficed for the government of his earthly life, but also enabled him to rise up to God and eternal happiness. (p. 169)

These gifts, according to Calvin, are so essential for human nature that if either of them is removed human beings are in fact no longer human but revert to being beasts (ibid:161). The fall of humanity into sin has not removed these gifts, but nevertheless, people are enslaved to $\sin$ (ibid:223). Calvin seems to be

6.In his commentary on Genesis 2:9, Calvijn ([1563] 1970) in one sentence refers to the free will of Adam, but he does not reflect upon this issue. In his commentary on Genesis 3:6, Calvin extensively deals with the corruption of human nature after the fall into sin. He rejects explicitly the opinions of Pelagius, but the issue of free the fall into sin. He rejects explicitly the opinions of Pelagius, but the issue of free will does not have his explicit attention. This indicates that Calvin's systematic reflections upon the issue of free will is to be found in his Institutes as he writes
explicitly in his commentary on Genesis $3: 6$.

7.Endowments are the innate capacities of an individual, group or institution. Primary endowments are: (1) self-awareness or self-knowledge, (2) imagination and conscience, (3) volition or will power. 
somewhat ambivalent on this matter. Is freedom of will for him more important than the will's enslavement to sin? Are human beings free or enslaved, human or beast? And, last but not least, what does an enslaved will imply for human responsibility? ${ }^{8}$ Calvin had to deal with these issues. The critiques of Albert Pighius had made Calvin sensitive to the problem of free will. ${ }^{9}$ Pighius asserts - principally due to the unclear way in which Calvin writes about the will in his Institutes of 1536 (Calvijn 1992) - that, according to Calvin, grace destroys one's sinful will and that God replaces it with a completely new will. ${ }^{10}$ Pighius, by contrast, stated that it is impossible for the will to be separated from the person, so he denied the principle of nova creatio [the completely new creation] of the human being and the human will. Calvin did, however, acknowledge these critiques by his opponent. In his latter, and last, edition of the Institutes, Calvin is therefore clearer in his arguments concerning the human will. To defend his view, he drew a distinction between the will as part of God's image and the will in its moral aspect. The first one cannot be separated from creation, the second can. This means that the will as the instrument to choose has remained in human beings despite their fall into sin, but the material contents of the will have been corrupted. To support his view, Calvin examines philosophers and theologians of previous centuries. He has great difficulty with most of them because they believe '... that man was corrupted only in the sensual part of his nature, that reason remained entire, and will was scarcely impaired' (ibid:225). Eventually Calvin uses a distinction that has been adopted by the scholastic tradition of the Middle Ages: 'I willingly admit this distinction, except in so far as it confounds necessity with compulsion' (ibid:227). The distinction Calvin refers to is that made by Bernhard of Clairvaux (cf. Brümmer 1994). Bernhard (see also Bernard of Clairvaux 1977) distinguishes will as follows ${ }^{11}$ :

- Freedom of necessity (liberum arbitrium). It is this freedom that is normally associated with free will. It means that the will acts in freedom and is not overridden by external reasons without the acceptance of the will (necessity). This is not just a freedom of approval but a freedom of choice. This freedom belongs to human nature and is not destroyed by sin.

- Freedom from sin (liberum consilium). Paul speaks about this in Romans 6:20-22. ${ }^{12}$

- Freedom from misery (liberum complacitum). Romans 8:21 refers to this freedom. ${ }^{13}$

8.Calvin explicitly mentions responsibility with respect to creation in God's ima. and the fall as he says (Calvin [1559] 1863:169): 'For there is need of caution, lest and the fall as he says (Calvin [1559] 1863.169): "For there is need of caution, lest we attend only to the natural ills of man, and thereby seem to ascribe them to the Author of nature; impiety deeming it a sufficient defense if it can pretend that when accused, to plead against God, and throw the blame of its guilt upon Him.'

9.Albertus Pigius (1490-1542), a Dutch Catholic theologian, mathematician and astronomer who furiously fought against protestant theologians such as Calvin and Luther (Calvin [1543] 1996)

10.In his Institutes of 1536, Calvin ([1536] 1992:61-67) speaks in a substantial way about regenerated human beings as if they are not sinners any more.

11.See also Bernard of Clairvaux (1977).

12.Romans 6:20-22 (ESV): For when you were slaves of $\sin$, you were free in regard to righteousness. But what fruit were you getting at that time from the things of which you are now ashamed? For the end of those things is death. But now that you have been set free from sin and have become slaves of God, the fruit you get leads to sanctification and its end, eternal life.

13.Romans 8:21: That the creation itself will be set free from its bondage to corruption and obtain the freedom of the glory of the children of God.
This framework helped Calvin to draw finer distinctions about human freedom. By sin, humankind is deprived of the last two kinds of freedom and can no longer choose what is right but only that which is evil. Freedom as it is contained in the first category, however, is necessarily implied in being human. Despite sin, human beings have this freedom, which is not destroyed by sin (Calvin [1559] 1863:227). Human will as will is saved, but its condition is pitiable. As Calvin (ibid) puts it:

In this will, then, man is said to have free will, not because he has a free choice between good and evil, but because he acts voluntarily, and not by compulsion. This is perfectly true: but why should so small a matter have been dignified by such proud a title? (p. 229)

We can conclude that Calvin acknowledged the freedom of the will as an essential characteristic of humanity but that this human instrument misses moral uprightness. The human will therefore necessarily sins because it is built on sin. Accordingly, human beings sin willingly and not by compulsion. Therefore, the human will is free to the extent that it always freely chooses to do evil instead of good. Humans remain, even after the fall, created in the image of God, but this image is, according to Calvin, corrupted and in need of conversion.

\section{God's providence}

From the above it is clear that humankind, as created by God, is free. The human will is free due to its creation in the image of God. At the same time, it is not free due to its sinful state. This means that the will is free to do what it wants, but it always chooses to do evil. However, how can this view of free will be combined with the doctrine of divine providence? Luther ([1525] 1990:80), for example, argues that '... this bombshell [divine providence] knocks "free will" flat, and utterly shatters it'.

In the Institutes, the relationship between Divine will and human will is limited to two paragraphs. ${ }^{14}$ This is, according to Paul Helm (2006:105), probably due to the fact that, at that time, little thought had been given to this extremely difficult matter. The fact that these two paragraphs belong to the Institutes is again due to a violent attack from an opponent. It was Sebastian Castellio ${ }^{15}$, a former friend of Calvin, who had difficulties with the Calvinistic doctrine that God also worked evil in humans. He (Calvin [1558] 2010) proposes this in a humoristic way:

What if both of these are the will of God? That is, if it is the will of God that Calvin is a prophet of God, and God wills also that we say he is a prophet of the Devil, then He wills a contradiction, and this is impossible. (p. 41)

Thus, according to Castellio, in opposition of Calvin's view on the providence of God, God is not the One who works evil

\section{Paragraphs 8 and 9 of chapter 16 , volume 1 .}

15.Sebastian Castellio (1515-1563), French humanist and theologian, had trouble with Calvin about several topics. The most important topic is the one about God's knowledge and especially his foreknowledge. Although he was recommended by knowledge and especially his foreknowledge. Although he was recommended by
Calvin in 1540 to be the rector of the Genevian School, in 1544, their friendship ended and they became enemies (Calvin [1558] 2010). 
in man, but humankind is doing good or evil according to its free will. In his De occulta Dei providential, Calvin argues much more extensively than in his Institutes about this matter. On the basis of several Bible texts, he shows that it is unbiblical to say that God is not in control of evil. Even Adam would not have fallen if God had not willed it (Calvin [1558] 2010:76).

This raises another problem. If people have no free will to choose between good and evil but all is done according to God's will, then two questions remain. Firstly, is God the author of sin, and secondly and connected to the first question, can one still be held responsible for one's actions? Calvin addresses these problems from three different perspectives, namely:

- He draws a radical distinction between divine and human affairs (Kirby \& Torrance 2003). Castellio reproaches Calvin for speaking as if he knows Gods hidden will. Calvin responds by asserting that, although there are hidden things in God, there is also consistency in God. So, through this consistency, one obtains some glimpses of God's will: 'In His secret will, by which He directs the actions of men, you will find nothing contrary to His justice' (Calvin [1558] 2010:46). The main observation when it comes to the relationship between divine and human will is formulated as follows by Calvin ([1559] 1863):

Thus we must hold, that while by means of the wicked God performs what he had secretly decreed, they are not excusable as if they were obeying his precept, which of set purpose they violate according to their lust. (p. 204)

- A second distinction drawn by Calvin ([1558] 2010: 78) is between first and second causes. God is the first cause of all and is caused by nothing. Everything that happens happens under God's command and permission (Calvin [1559] 1863:179). However, this does not imply that all happens without human beings. Human beings cannot penetrate to the first cause, and therefore, they have to understand their responsibility as if all future things are open to every side (Calvin [1545] 2006):

For we must not suppose that God works in an iniquitous man as if he were a stone or a piece of wood, but He uses him as a thinking creature, according to the quality of his nature which He has given him. (p. 128)

- A final perspective (Calvin [1545] 2006:117) is the distinction that Calvin draws between conditional necessity (necessitate secundus quid) and unconditional necessity (necessitas absoluta). Calvin uses this scholastic distinction to show that God's plan is done but that this is not an intrinsic necessity because human beings are and will be kept responsible for their actions. Good and evil belong to God's plan, but human beings have their own place and responsibility before God's face.

We can conclude that Calvin shows us a complex approach. Human beings are created as beings with free will. This free will cannot be denied, but it is entirely corrupted. This implies that one is not forced to sin but that $\sin$ is nonetheless done necessarily. Human beings will nothing but sin, and sin is done willingly. Besides this, we have to do with a God who directs and controls both good and evil in human beings. By using different qualifications, Calvin maintains a certain qualified freedom to ensure human responsibility. With reference to the different perspectives on determinism, one may posit that Calvin is a compatibilist in his understanding of human will.

\section{Neurobiology and free will}

As complicated as it is to figure out what the will is in Calvin's view, as easy is it to trace the view of the neurobiologist Swaab in this matter. His view is related to the fact that many things in daily life are done unconsciously (Swaab 2014:329). Driving, for instance, can be done without immediate awareness of driving until something unexpected happens. It is even possible that one can actually be reading these sentences without consciously reading. ${ }^{16}$ These two examples show how our lives are directed to a certain extent by unconscious processes in our brain.

To understand the deterministic view of the neuroscientist Swaab, we need an extensive look at Benjamin Libet's research. This research has axially laid the basis of the determinism in the neuroscience of Swaab (Swaab 2010:386). Benjamin Libet et al. (1983) have, in their famous study, demonstrated the function of the brain with regard to these unconscious activities. ${ }^{17}$ Through research with electroencephalogram (EEG), Libet shows that brain activity is present before it is perceived by the subject (Haggard \& Martin 1999; Libet et al. 1983). This EEG shows that about one second before the person indicates a tendency to press a button, there are already electric activities in the brain, indicating that the brain has already taken this decision.

Libet himself remained convinced that, despite the results of his investigation, one has free will. This conviction was based more on his view on human life than on his brain research. ${ }^{18}$ Libet's experiment has been refined and repeated, and the results are fixed (e.g. Libet et al. 1999) so that many neuroscientists are today convinced that human beings do not possess free will. Dutch neuroscientist Victor Lamme, for example, puts it as follows (Lamme 2010: 213): 'Our activities do not follow our thoughts. It is just the opposite. The chatter box is building a beautiful story around our motivations and intentions without knowing the real truth. ${ }^{19}$ A human being is subject to the whims of his or her own brain. As Susan Blakemore, quoted by Tallis (2011:52) says: 'The human brain is a machine which alone accounts for all our actions,

16. Because this sort of events happens many times a day according to Wegner $(2003 \mathrm{a} / \mathrm{b})$ it is better to speak of an 'unconscious will' than of a 'free will'.

17.Much of the contemporary case for the illusory nature of free will is derived from the experimental work of Libet and his colleagues. T. Bayne (2011) explains: 'Libet's studies concerning the neural basis of human agency (...) the most influential rebutting (of free will, authors) objection in the current literature'.

18.With reference to the different views on free will Benjamin Libet can be called a compatibilist.

19.'Chatter box' (kwebbeldoos in Dutch) is Lamme's translation of the by Gazzaniga used term 'brain interpreter'. Lamme explains it as follows (Lamme 2010: 207): 'Ganzagia relates the chatterbox to the tendency of the human brain which always wants to look for explanations' 
our most private thoughts, our beliefs ... All our actions are products of the activity of our brain.' This brain, completely uncontrollable at will, acts in the way it does because its patterns of operation are fixed since birth. This pattern of actions is not only determined by our brains but also by external factors that affect the brain. Swaab (2014) interprets this as follows:

Many genetic factors and environmental influences in early development, through their effects on our brain development, determine the structure and therefore the function of our brains for the rest of our lives. As a result, we start life not only with a host of possibilities and talents but also many limitations, like a congenital tendency to addiction, a set level of aggression, a predetermined gender identity and sexual orientation, and a predisposition for ADHD, borderline personality disorder, depression or schizophrenia. Our behavior is determined from birth (p. 327).

It is therefore conceivable that brain science engages in many other fields of science due to their view that the brain rules all. Besides, psychology can, they argue, with the above evidencebased research, make statements about legal, philosophical and theological aspects of life. Swaab (2014) states:

In other words, our genetic background and all the factors that permanently affected our early brain development saddle us with a host of internal limitations; we are not free to decide to change our gender identity, sexual orientation, aggression level, character, religion, or native language. Nor can we decide to have a certain talent, or to abstain from thought (p. 328).

Other scientists such as Sternberg (2010) share this view. It follows therefore that ethics are included in the condition of the human brain. The task of the human brain during one's life is only to ensure that the body functions well and to give the brain the opportunity to survive. A more deterministic vision of live is almost impossible, and it includes the implication that ethics disappear.

\section{Evaluation}

The research question of the article is whether Calvin's views on free will and that of neurosciences are interchangeable. Is there ultimately any other difference between the two visions than that the one says that God determines our actions whilst the other states that the brain determines our actions?

From the description above, it has become clear that Calvin's doctrine of providence is a nuanced determinism. Calvin argues that there is stratification and complexity in the way God controls everything in this world. It is good, according to Calvin, to know that God had foreordained all and is in control of good and evil, but we do not know how things will proceed. It is important to notice that Calvin distinguishes principally between God's order and the order of human beings. These two orders are not to be mingled but must be distinguished clearly. Therefore we should not worry about God's hidden plan, but we should be aware of our own responsibility. Moreover, human will does not act under compulsion but is free in its choices. Although God has everything in his hand, humans voluntarily want what they want. Human beings are therefore fully responsible for their acts and should therefore also bear the consequences of their actions.

The view of neurodeterminism is far more rigid and less nuanced. Man is subject to the iron law of nature, and there is no way to escape this law. Therefore, free will is not an issue; it is only an illusion. In this view, very little remains of individual responsibility. It is therefore not strange that Swaab (2014:) writes:

I am curious to see how long it will take before society starts to think differently about other actions and behaviors [other than homosexuality - $A M / W v V]$ that are now thought to be subject to free will, like aggressive and delinquent behavior, pedophilia, kleptomania and stalking. Society's acceptance of those behaviors as innate would have far-reaching consequences in the treatment of offenders (p. 338).

We can call this view on human will strong determinism.

The whole problem can be explained in a simple way. Swaab argues that 'we are our brain', and from the description, it is clear how strong this claim is in the case of his neuroscientistic view. Would a Calvinist, however, ever say: God is our brain? The answer to this question makes the distinction between both views clearer. This means that the answer to the central question of this article must be negative: The view of the neurosciences on free will is not compatible with Calvin's view. Whilst Calvin can be described as compatibilist or weak determinist, the neuroscience of Swaab must be characterised as strong determinism. In Swaab's worldview, there is nothing but matter whilst Calvin's worldview draws a distinction between the material world and the invisible reality of the Creator. By this duality (to be distinguished from dualism) in Calvin's worldview, he prepared the conceptual possibility to free humanity from matter so that human beings are not enclosed by natural processes but have a real responsibility and a certain creaturely autonomy.

It remains remarkable that the doctrine of Calvin is rejected whilst the much more rigid worldview of neuroscience is eagerly embraced. One would have expected that Calvin's moderate concept of free will would have been preferred to the deterministic approach of neuroscience. It is in any event a confirmation that human beings are not free in their choices.

\section{Acknowledgements Competing interests}

The authors declare that they have no financial or personal relationship(s) which may have inappropriately influenced them in writing this article.

\section{Authors' contributions}

Both authors wrote the article together whilst Ammiel Meuleman was the project leader. 


\section{References}

Achtner, W., 2010, Willensfreiheit in Theologie und Neurowissenschaften, ein historisch-systematische Wegweiser, Wissenschaftliche Buchgesellschaft, Darmstadt.

Augustin, A., 2010, De libero arbitrio, on the free choice of the will, on grace and free choice and other writings, ed. \& transl. P. King, Cambridge University Press, Cambridge.

Bayne, T., 2011, 'Libet and the case for free will scepticism', in R. Swinburne (ed.), Free will and modern science, pp. 25-46, Oxford University Press, Oxford/New York.

Bernard of Clairvaux, 1977, On grace and free choice, transl. D. O'Donovan \& C. Greenia, Cistercian Publications, Collegeville. [The works of Bernhard of Clairvaux, vol. 7, treatise III].

Brümmer, V., 1994, 'On not confusing necessity with compulsion: A reply to Paul Helm', Religious Studies 30(4), 437-455.

Calvijn, J., [1536] 1992, Institutie 1536, Onderwijs in de christelijke religie, trans. W. van 't Spijker, De Groot Goudriaan, Kampen.

Calvijn, J., [1563] 1970, Genesis, uitlegging van Johannes Calvijn, transI. S.O. Los, de Groot Goudriaan, Kampen.

Calvin, J., [1543] 1996, The bondage and liberation of the will: A defence of the orthodox doctrine of human choice against Pighius, transl. A.N.S. Lane \& G.I. Davies, Baker Books, Grand Rapids.

Calvin, J., [1558] 2010, The secret providence of God, transl. P. Helm \& K. Goad, Crossway, Wheaton.

Calvin, J., [1559] 1863, Institutes of the Christian religion, transl. Henry Beveridge, Edinburgh, T \& T Clark.

Campbell, J.K., 2011, Free will, Polity Press, Cambridge.

Debestseller60, n.d., Wij zijn ons brein, viewed 18 April 2014, from http://www.cpnb. $\mathrm{nl} / \mathrm{bs} /$ index.asp?searchString=Swaab

Edwards, J., [1754] 2009, Freedom of the will, Yale University Press, Yale. [The works of Jonathan Edwards, vol. 1]

Haggard, P., \& Martin, E., 1999, 'On the relation between brain potentials and awareness of voluntary movements', Experimental Brain Research 126(1), 128-133.

Härle, W., 2006, 'Die unvereinbarkeit des Determinismus mit Luthers Theologie unter bezugnahme zur aktuellen Neurobiologischen Diskussion', in W. Härle \& B. Mahlmann-Bauer (eds.), Prädestination und Willensfreiheit: Luther, Erasmus, Calvin und ihre Wirkungsgeschichte: Festschrift für Theodor Mahlmann zum 75. Geburtstag, pp. 1-22, Marburger theologische Studien, Leipzig.

Helm, P., 2006, John Calvin's ideas, Oxford University Press, Oxford/New York.

Jonkers, P., \& Sarot, M. (eds.), 2013, Christian faith, free will and neuroscience: Embodied Religion, Proceedings of the 2012 Conference of the European Society for Philosophy of Religion, Ars Disputandi, Utrecht.
Kane, R. (ed.), 2011, The Oxford handbook of free will, Oxford University Press, Oxford/New York.

Kane, R.H., 1999, 'Responsibility, luck, and chance: Reflections on free will and indeterminism', Journal of Philosophy 96, 217-240.

Kane, R.H., 2007, 'Libertarianism', in J. Fischer, R.H. Kane, D. Pereboom \& M. Vargas (eds.), Four views on free will, pp. 5-43, Blackwell, Oxford.

Kirby, W., \& Torrance, J., 2003, 'Stoic and Epicurean?: Calvin's dialectical account of providence in the Institutes', International Journal of Systematic Theology 5(3), 309-322.

König A., 1996, 'Providence', in A. van Egmond \& D. van Keulen (eds.), Freedom: Studies in reformed theology, pp. 181-194, Callenbach, Baarn.

Lamme, V., 2010, De vrije wil bestaat niet, over wie er echt de baas is in het brein, Bert Bakker, Amsterdam/Antwerpen.

Lane, A.N., 1981, 'Did Calvin believe in free will?', in H.H. Rowdon (ed.), Biblical and historical essays from London Bible College, London Bible College, London.

Libet, B., Gleason C.A., Wright, E.W., \& Pearl, D.K., 1983, 'Time of conscious intention to act in relation to onset of cerebral activity (readiness potential): The unconscious initiation of a freely voluntary act', Brain, a journal of neurology 106(3), 623-642.

Libet, B., Freeman, A.K., \& Sutherland, K., 1999, 'Editor's introduction: The volitional brain', Journal of Consciousness Studies 6(8/9), ix-xxiii.

Luther, M., [1525] 1990, The bondage of the will, transl. J.I. Packer \& O.R. Johnston, Revell, Grand Rapids.

Mawson, T.J., 2011, Free will: A guide for the perplexed, Continuum, London.

Oomen, P. (ed.), 2013, Vrije wil, een hersenkronkel?: Wetenschappers en filosofen over een fascinerende vraag, Klement, Zoetermeer.

Sternberg, E.J., 2010, My brain made me do it: The rise of neuroscience and the threat to moral responsibility, Prometheus Books, New York.

Swaab, D.F., 2014, We are our brains: A neurobiography of the brain, from the womb to alzheimer's, Spiegel \& Grau, New York

Swinburne, R., 2013, Mind, brain \& free will, Oxford University Press, Oxford.

Tallis, R., 2011, Aping mankind, neuromania, Darwinist and the misrepresentation of humanity, Acumen, Durham.

Van Ruler, H., 2011, 'De vrije wil van Homerus tot Kant', in M. Sie (ed.), Hoezo vrije wil?, pp. 33-61, Lemniscaat, Rotterdam.

Van Vlastuin, W., 2012, 'A retrieval of Edwards' concept of free will', Theologica Wratislaviensia 7, 93-111.

Van Vlastuin, W., 2013, 'Neurocalvinism as a paradigm for neuroscience', in P. Jonkers \& M. Sarot (eds.), Embodied religion, pp. 279-292, Ars Disputandi, Utrecht.

Wegner, D.M., 2003a, 'The mind's best trick: How we experience conscious will', Trends in Cognitive Sciences 7, 65-69.

Wegner, D.M., 2003b, 'The illusion of conscious will', MIT Press, Cambridge. 